\title{
The Conversion in the English Language
}

\author{
Gadimova Laila Sahib ${ }^{1}$ \\ ${ }^{1}$ Azerbaijan University of Languages, Baku, Azerbaijan \\ Correspondence: Gadimova Laila Sahib, Azerbaijan University of Languages, Baku, Azerbaijan. E-mail: \\ gadimova1@yahoo.com
}

Received: December 22, 2015 Accepted: January 20, 2016 Online Published: January 31, 2016

doi:10.5539/ijel.v6n1p202

URL: http://dx.doi.org/10.5539/ijel.v6n1p202

\begin{abstract}
The article deals with the investigation of the conversion in the English language. It states that the conversion is one of the main methods of enriching the vocabulary of a language. As the English language is an analytical one, the conversion is more specific for English. Many linguists have been interested in the problem of the conversion. The author claims that the conversion is a productive method of word forming in English. The author also investigates the study of new word forms from various parts of speech, such as the nouns, the adjectives, the verbs, the conjunctions and so on. Basing upon different sources the author comments on the term "conversion" and provides examples from such fields of linguistics as lexicon, grammar and phonetics. The phenomenon of conversion is widely spread in English. It is connected with the fact that there are not enough morphological indicators, flexions of parts of speech in this language. The author claims that conversion is one of the main reasons of the rich word stock of the English language.
\end{abstract}

Keywords: word stock, conversion, word formation, productive, method, morphological, flexions

\section{Introduction}

The rich word stock is one of the main factors in every period of the society, and in every communication. The changing of the sematics of the word, the forming of the new lexical units and the succession of the communication process is realized not the by the help of the words that are in the vocabulary of the language but also by the help of borrowed words from other languages or by the help of the words that are conversed in the language. Conversion can be observed in various fields of the language such as lexics, grammar and even in phonetics. The conversion in grammar, or grammatical conversion is commonly observed in the active and in the passive voices of the verb. Such kind of conversion is expressed by means of the same words.

For example, He reads a book. O, kitab oxuyur.

The book is read. Kitab oxunur.

In lexicsthe conversion consists of the words that express mutal relationship between the subject and the predicate.Those words have double valency, and they are realized through the lexical conversion. During the conversion words are changed not only according to their morphological structure but also to their functions. Therefore, this kind of process can be called functional changing. Let us compare the meanings of the word "round" as different parts of speech in the following sentences:

He was knocked out in the first round.

Round the number off to the ten.

The neighbors gathered round our barbecue.

The moon was bright and round.

People came from all the country round.

As we see the word "round" is used as different parts of speech such as the noun, the preposition, the adjective and the adverb.

\section{Scope of the Study}

We should like to state that generally the conversion is called the word forming process. In this process the formed word refers to a new class of the word without taking any suffixes. This kind of conversion is called a 
zero-word creating process. Yartseva writes about the conversion: "the style of a new word forming process without using any special word forming affixes; it is the kind of process in which one word is changed into other part of speech" (Soviet encyclopedia, 1990).

Let us take two kinds of words and compare them inside the sentences: single and simple. Both of these words are adjectives. The difference is that the word "single" can be used as a verb without changing its form. For example,

They singled him out at once as a possible victim.

In this sentence the word "single out" is translated into the Azerbaijani language as seçmək (to choose). Unlike it the word "simple" cannot be used as a verb without taking any suffixes. For example,

Quilts will simplify (not simple) their needs.

As we see the word "simple" takes the verb forming suffix-ify. It is translated into the Azerbaijani language as asanlaşdırmaq, sadəlaşdirmək.

In the first example,we observe the conversion, namely the zero-word creating process, but in the second sentence the conversion is not observed as the word "simplify" is a derivative verb. It is important to mention that most linguists support the idea of word forming rather than the idea of being syntactic form of the word in the attitude of the conversion. We can name the linguists who prefer the idea of word forming process such as O.S.Akhmanova, Y.A.Jluktenko, E.S.Kubryakova, A.İ.Smirnitsky, Y.S.Stepanov, V.N.Yartseva, H.Marc and and others (Akhmanova, 1966). These linguists also appreciate the conversion as a productive word forming process (Aminova, 2004).

One of the main reasons that conversion is considered to be an active style of word forming process is that native speakers use them in order to save the space. As Chernoqorova writes "the structure of a line language is formed by the functional elements such as the prepositions and the affixes. They are used for the purpose of syntactical economy" (Chernogorova, 1981).

There exist some differences in the commentment of the conversion depending on the mutual relationship of main and derivative words. In the narrow commentment of the conversion the main and derivative lexems of it coincide with one another. This kind of criterion of the conversion was analysed by Smirnitsky. The author writes about the problem: "the conversion is such a kind of word forming process that only the paradigm of a word is used as aword forming style. It is realated to the fact that while one lexeme is changed into the other one it keeps its main form".

According to Peshkova the process of forming a new lexeme (namely the conversion) expresses the mechanism of changing functions between the language elements (Smirnitskiy, 1954).

The conversion is observed mainly among the notional parts of speech such as the nouns, the adjectives and the verbs. The most productive ones among these are the adjectives and the verbs. It is necessary to state that the conversion changes not only the functions of the words but also their meaning differences according to the original meanings.

For example, the word "paper" has four meanings as a noun:

a) material in thin sheets made from wood or cloth

b) a newspaper

c) a piece of writing

d) wallpaper, etc.

We should like to draw your attention to the fact that the word "paper" is noticed to be used as a transitive verb in the example (d). For example:

The workers papered the room red.

According to investigations the word forming process has the following methods:

1) The word forming process by adding various affixes to the root of the word;

2) The word forming process by adding words to the root of the word;

3) The new word forming process by converting one part of speech into another one;

4) The word forming process by giving a new meaning to the word.

Some linguists claim that the new word forming process in different languages have various kinds: 
a) The word forming process by using prefixes;

b) The word forming process by using postprefixes;

c) The word forming process by using inflections.

These divisions were mainly supported by Akhundov. He claimed that there exists such a kind of word forming process by using prefixes, suffixes and postprefixes as well. It is important to state that this kind of word forming process is often observed in the English language.

The word forming process by adding words to the root of the word refers to the synthetic way of the word forming. The synthetic way of the word forming process has two kinds:

a) The process by combining two words. For example, in the Azerbaijani language: istiot, düzbucaqli, üzbəüz, etc. The compound nouns in the English language: appletree, snowball (noun-stem+noun-stem); the compound verbs: daydream, browbeat (noun+verb stem), verb+verb), etc.

b) The process by combining three or more words. For example, in the Azerbaijani language: əlüzyuyan, etc.

\section{Kinds of Conversion}

Conversion can be observed in the four levels:

1) Syntactic;

2) Morphological-syntactic;

3) Semantic-syntactic;

4) Semantic.

1. The syntactic conversion refers to all parts of speech. It describes the word forming process that one part of speech can be used instead of another part of speech without any change.

2. The second kind of the conversion means that one part of speech is converted into the other one and takes the affixes of the grammatical categories of that part of speech and forms a new word. This kind of conversion is called a morphological-syntactical one.

3. The semantic-syntactic conversion is the third kind of the conversion, and it mostly refers to the substantivization process.

4. If a word loses all its semantic and grammatical relations with one part of speech and converts into the other one, this kind of conversion is a semantic one.

Now we are going to explain how to convert nouns from verbs. We can say that nearly all single morpheme verbs can form the noun conversion. If we pay attention, we can see that semantically those nouns are related to the origin of the verbs in various ways:

\section{Situation (state) (thought or perceiving, idea)}

doubt (şübhələnmək); the state of doubting (şübhə);

want (istəmək); what is wanted (istək, arzu, tələbat);

\section{More examples:}

desire - arzulamaq; arzu; love - sevmək; sevgi; hate - nifrət etmək; nifrot; smell-qoxumaq, iylanmək; qoxu, iy; taste-dadmaq; dad.

\section{Event or employment}

Search (axtarmaq); the activity of searching (axtarış);

Laugh (gülmək); the act of laughing (gülüş);

\section{More examples:}

attempt - cəhd etmək; cəht; hit - vurmaq, döymək; zərbə;release - həyata keçirmək, yerinə yetirmək; dərk etmək; anlama; satı̧; swim - üzmək; üzmə; shut-down - bağlamaq;bağlama; teach-in - təlim etmək, öyrətmək; öyranmo

\section{The result of the action}

catch (tutmaq, yaxalamaq); what is caught (tutma, tutlma; ov);

find (tapmaq); what is found (tapıntı, tapılmış şey); 


\section{More examples:}

to reject - etiraz etmək, radd etmək; reject - zay, brak; to buy - almaq, satın almaq; buy - satın alınmış şey, bazarliq; hnad out-paylamaq; hand-out-xərclik, to answer-cavab vermək; answer-cavab; to bet - morc galmak; bet-marc

\section{The doer of the action}

help (kömək etmək); one who helps (kömək edən);

cheat (xəyanət etmək, aldatmaq); one who cheats (xəyanət edən, aldadan);

\section{More examples:}

to coach - maşq etmək, təkrar etmək; coach - repetitor, məşqçi; to flirt - eşqbazlıq etmək; flirt - eşbazlıq edən, to scold - danlamaq, mazəmmat etmək; scold-deyingan adan (qadin)

\section{The tools used for performing the action}

cover (örtmək; qapamaq, bağlamaq); used to cover something (qapaq; üz; sarıma, bükmə; örtük; çexol; futlyar; qab);

wrap (bürümək, sarımaq, bağlamaq, bükmək); used to wrap something (şal, örpək; çiyin örtüyü; böyük şal);

\section{More examples:}

to cure - müalicə etmək; cure - dərman, çar; to paper - kağıza bükmək; oboy vurmaq; paper - kağız, to wrench - dartıq çıxartmaq, qopartmaq; wrench - dartma,sıxma, burma; çıxıq, çıxıq yeri, burxuq;

\section{The place of the action}

pass (keçmək); where one has to pass (keçid);

walk (gəzmək); a place for walking (yol (piyadalar üçün), gəzmə, yerimə);

\section{More examples:}

to divide - bölmək; divide - bölgü; taqsim, to turn - dönmək, hətəkət etmək; turn - hərəkət, to drive - getmək, galmək, sürmək; drive - getmə, galmə, sürmə; to retreat - uzaqlaşmaq, geri çəkilmək; retreat - geri çəkilmə, uzaqlaşma.

We should like to stress that the simple nouns which are formed from the verbs can be used with the verbs have, take, make, give and so on. For example,

have a look (smoke, swim, try, wash) - ötəri nəzər salmaq (siqaret çəkmək, üzmək, çalışmaq, yumaq); take a walk (ride, glance, rest, shower) - kiçik gəzintinə çixmaq,getmək (atla gəzməyə getmək, nəzər salmaq, dincəlmək, duş qəbul etmək); give a cry (grant, start, laugh, shudder) - ağlamaq (yol vermək, başlamaq, gülmək, titrəmək); make a move (guess, offer, slip, attempt) - hərəkət etmək, köçmək, tərpənmək (güman etmək, təklif etmək, sürüşmək, cəhd etmək), etc.

Now let us use these kinds of verbs in the sentences:

You'd better have another think. (Yaxşı olar ki, bir daha fikirləşəsən).

Let's take a walk to the park. (Gəlin parka gedək).

He made an interesting offer to his girl friend. ( $\mathrm{O}$, q1z dostuna maraqlı təklif etdi).

The conversion of phraseological verbs is also interseting. The phraseological verbs such as hand-out (xərclik), stand-by (istifadəyə hazır; hazır vəziyyət), lay-by (velosiped dayanacağı), teach-in (ictimai maraqla bağlı qeyri-rəsmi mühazirə, çıxış), shut-down (bağlanma (müəssisə və s.), etc. can be given as examples. The word "hand-out" is formed from the verb hand out, the word "stand-by" is formed from the verb stand by etc.

We should like to stress that when the phraseological verb is changed into the noun, the verb and the particle can be separated from each other. For example,

Flow over (daşqın, subasma), to overflow (daşmaq, axmaq, tökülmək), breakout(püskürmə, yarılma), to outbreak (püskürmək, yarılmaq), fall down (süqut, yıxılma, iflas), to downfall (süqut etmək, dağılmaq, yıxılmaq), take in (qəbul, çəkmə, alma), to intake (qəbul etmək, almaq, çəkmək),etc.

Now we want to investigate the adjectives that change into nouns. We want to note from the beginning that it is not abnormal that the adjectives can be changed into the nouns. Unlike the verbs the adjectives that can be used as the nouns cannot take all properties of the nouns. Some adjectives can take all properties of nouns while others cannot. The conversion that some adjectives take all properties of the nouns and change into the nouns is 
called full conversion. The other group of adjectives that cannot take all properties of nouns and this kind of conversion is called the partial one.

The adjectives that change fully into the nouns take all properties of nouns. For example, they can take the indefinite article as nouns, they can take the plural ending $-\mathrm{s}$ (-es) etc. For example:

\begin{tabular}{ll}
\hline The noun & The adjective \\
\hline awhite & Aliberal \\
anative & Republican \\
Finals & necessaries \\
Drinkables & Valuables \\
\hline
\end{tabular}

a. Come to the fire and have a warm.

b. The inexperienced young hopefuls were invited by the manager.

c. Poor innocents!

d. I'm one of his familiars

As we stated above the partial adjectives do not take all properties of the nouns. They can take only the definite article (the) and denote the whole class. For example,

Thepoor (poor people), the rich (rich people), the young (young people), the wounded (wounded people), the poorer (people who are poorer), the more affluent (people who are richer) the most corrupt (people who are more corrupted), etc.

As we see the words that are formed by the partial adjectives are used to denote a whole class:

the young = young people, the wounded $=$ wounded soldiers.

These kinds of words can also be referred to individual persons. For example, the deceased, the departed, the accused, the deserted, the condemned etc.

a. The old man is the poorest among the poor.

b. The young should not look down upon the old.

Now we want to analyze the words that change their meanings in the sentences. These kinds of conversion are changed from the conjunctions, modals, verbals, prepositions, etc.

Would you like to go a with or a without?

Better to be an also-ran than a never-was.

His argument contains too many ifs and buts.

Life is full of ups and downs.

Rubber gloves are a must if your skin is sensitive to washing powders.

There are such kinds of nouns that their being used as verbs depends on the context; they are chosen depending on the meaning of the sentences in the texts. This kind of conversion is considered to be productive, and they are easy to be found. For example,

The expresssion "to elbow one's way through the crowd" (kütləni yarıb/itələyib keçmək) is better to be used instead of the expression "to push one's way through the crowd with one's elbow".

As we see the first expression sounds better than the second one.

Other examples:

They now eat better food, live in better houses, and wear better clothes than ever before.

Of course, this sentence is more logical, more concise than this one: "They are better fed, better housed, and better clothed than ever before."

If we pay attention to the nouns that are changed from the verbs, we see that they keep their real meanings semantically in different ways: 


\section{The first group of words:}

to pocket the money - to put money into the pocket

to can the fruit - to put the fruit into cans

to bottle the wine

to garage the car

to corner the bicycle

to shelve the books

\section{The second group of words:}

to shelter the refugees - to give shelter to the refugees

to oil the machine - to provide the machine with oil

to butter the bread

to fuel a ship

to grease the oven

to arm the army

to finance the company

to coat the cake with cream

\section{The third group of words:}

to skin the lamb - to remove the skin from the lamb

to juice the oranges - to remove the juice from the oranges

\section{The fourth group of words:}

to pump water - to bring water with a pump

to knife the steak - to cut the steak with a knife

to fiddle the cigarette - to play the cigarette with a hand

\section{The fifth group of words:}

to nurse the baby - to be the nurse for the baby

to captain the team - to act as the captain for the team

to parrot the teacher - to repeat the teacher's words

\section{The sixth group of words:}

to cash the cheque - to change the cheque into cash

to orphan the boy - to make the boy an orphan

\section{The seventh group of words:}

to mail the letter - to send the letter by mail

to bicycle - to go by bicycle

As we see these verbs are usually transitive verbs, but while investigating we have found some intransitive verbs, too. For example,

to helicopter - to fly by helicopter

to boat - to go by boat

\section{Some other examples:}

a. That young writer pens gripping tales.

b. Thumb through any dictionary and you find this word.

d. He can't stomach such an insult.

e. He tried to Hamlet his chance and then he regretted for it.

f. Let's weekend in the country. 
g. Robert roomed next to me.

The conversion can also be observed in pronunciation, writing, or stress changings.

\begin{tabular}{ll}
\hline The voiceless consonants & The conversion of voiced consonants \\
\hline Nouns & Verbs \\
house /-s/ & house/-z/ \\
use /-s/ & use/-z/ \\
mouth /- $\theta /$ & mouth/-e/ \\
shelf $/-\mathrm{f} /$ & shelve /-v/ \\
sheath /- $\theta /$ & sheathe/-e/ \\
\hline
\end{tabular}

The stress changing can be seen in two syllable words. In the words used as nouns the stress is on the first syllable, in the words used as verbs the stress is on the second syllable.

'conduct (n) - con`duct (v), 'extract (n) - ex’tract (v), ’permit (n) - per`mit (v), etc.

Some pronunciation conversion can also be observed. For example,

breath /e/- breathe /i:/, bath /a:/ -bathe /ei/, food-feed, blood-bleed.

\section{Conclusion}

The conversion is a widely spread word forming process in the English language. The examples used in the article prove it. It happens because there are not enough morphological indicators in the parts of speech in the English language. In the English language there are not morphological flexions of the parts of speech. Therefore, the conversion is often observed among the parts of speech such as the nouns, the verbs, the adjectives, the adverbs, etc. As it is known the word stock of the English language is very rich. Relying on our investigation about the conversion we can say that English must be grateful to its word stock for this.

\section{References}

Akhmanova, O. S. (1966). Dictionary of linguistic terms. M .: Soviet Encyclopedia.

Aminov, A. (2004). Structural-semantic features of new slangs in English and French. Dis. ... Cand.filol. Sciences. Ufa.

Chernogorova, G. P. (1981). Model (S1 + S2) and its associated problems, some pro-adjectivization the Exploration of formative structure and compatibility of linguistic elements-ing in the Romance languages. Chelyabinsk: PRF.

Close, R. A. (1979). A Reference Grammar for student of English. Moscow.

Ilyish, B. A. (1971). The Structure of Modern English. Leningrad.

Kobrina, N. A., \& Korneyeva, E. A. (1986). An English Grammar, Suntax. Moscow.

Linguistic Encyclopedic Dictionary. (1990). Ed. V. N. Yartseva. M .: Soviet Encyclopedia.

Quirk, R., \& Greenbaum, S. (1982). A University Grammar of English. Moscow.

Smirnitsky, A. I. (1954). About the conversion to English. Foreign languages at school.

Swan, M. (1984). Practical English Usage. Moscow.

\section{Copyrights}

Copyright for this article is retained by the author(s), with first publication rights granted to the journal.

This is an open-access article distributed under the terms and conditions of the Creative Commons Attribution license (http://creativecommons.org/licenses/by/3.0/). 